CASSOWARY Volume 1 (1): 55 - 62

ISSN : 2614-8900

E-ISSN : 2622-6545

CProgram Pascasarjana Universitas Papua, https://pasca.unipa.ac.id/

\title{
Kinerja Sapi Bali Jantan yang diberikan pakan Rumput Gajah (Punnisetum purpureum) subtitusi fermentasi Jerami Padi
}

\author{
Performance of Males Bali Cows fed with Elephant Grass (Punnisetum purpureum) \\ substitute Rice Straw fermentation
}

Alimuddin $^{1)}$, M. Jen Wajo ${ }^{2)^{*}}$, Marlyn N Lekitoo ${ }^{2)}$

${ }^{1)}$ Balai Penelitian Pertanian Provinsi Papua Barat

Jalan Basecamp Komplek Perkantoran Pemprov, Anday, Manokwari, Kodepos 98315

Papua Barat Indonesia.

2) Jurusan Produksi Ternak FAPET UNIPA

Jalan Gunung Salju Amban, Manokwari, Kodepos 98314, Papua Barat Idonesia

*Email: m.wajo@unipa.ac.id

\begin{abstract}
The research was aimed to study Bali bulls fed with Pennisetum purpureum with fermented rice straws substitution in Manokwari Regency, West Papua was conducted experimentally with 12 Bali bulls that have average weight of $176.02 \pm 38.35 \mathrm{~kg}$ with $2-2,5$ years old for 5 months duration. The study was designed using complete randomized design of nested pattern with 3 (three) treatments, 4 (four) replications and 4 (four) times weighing, with an assumption that Bali bulls are nested during weighing time. The results of this study showed that Penicetum purpureum substitution with fermented straws did not significant on Bali bulls body weight. The duration of fermented rice straws feeding that substituted with Penicetum purpureum significant for Bali bulls weight gain with the average absolute weight gain is $0,68 \mathrm{~kg} /$ day, as well as relative body weight gain of $0,033 \mathrm{~kg} /$ day. The potential of rice straws in Manokwari Regency might be utilized as Bali bulls feed as many 9.431 - 46.846 cattle.
\end{abstract}

Key words : Bali cattle, Penicetum purpureum, Rice straws, Probion, Urea

ABSTRAK : Penelitian produktivitas sapi Bali jantan yang diberikan pakan rumput gajah (Pennisetum purpureum) dengan subtitusi jerami padi fermentasi di Kabupaten Manokwari Papua Barat, dilakukan secara eksperimental dengan menggunakan 12 ekor sapi Bali jantan yang memiliki berat rata-rata 176.02 \pm 38.35 dengan umur berkisar antara 2-2,5 tahun Selama 5 bulan. Penelitian di rancang dengan mengunakan Rancanagan Acak Lengkap (RAL) pola tersarang dengan 3 (tiga) perlakuan, empat ulangan serta 4 (empat) kali waktu penimbangan, dengan asumsi bahwa berat sapi Bali jantan tersarang pada waktu penimbangan. Hasil penelitian menunjukan bahwa Subtitusi rumput gajah (Penicetum purpureum) dengan fermentasi jerami tidak memberikan pengaruh yang signifikan terhadap bobot badan (BB) sapi Bali jantan. Lama waktu pemberian i jerami padi fermentasyang mensubtitusi rumput gajah (Penissetum purpureum) berpengaruh secara signifikan terhadap pertambahan berat badan (PBB) sapi Bali jantan dengan pertambahan badan absolut rata-rata $0,68 \mathrm{~kg} / \mathrm{hari}$, serta pertambahan badan relatif 0,033 $\mathrm{kg} /$ hari. Potensi jerami padi di kabupaten Manokwari dapat dimanfaatkan sebagai pakan untuk sapi Bali sebanyak 9.421 - 46.846 ekor. 
CASSOWARY Volume 1 (1): 55 - 62

ISSN : 2614-8900

E-ISSN : 2622-6545

(CProgram Pascasarjana Universitas Papua, https://pasca.unipa.ac.id/

Kata Kunci : Sapi Bali, Rumput gajah, Jerami padi, Probion, Urea

\section{PENDAHULUAN}

Permintaan daging di Indonesia setiap tahunnya meningkat sebesar 6$8 \%$, terutama di daerah yang padat penduduknya. Produksi daging nasional tahun 2014 sebesar 435.086,19 ton, sementara kebutuhan 593.516,62 ton. Tahun 2017 produksi daging 452.231,45 ton dan kebutuhan nasional sebesar 711.114,96 ton. (Puslitbangnak, 2017).

Fenomena tersebut menunjukkan adanya kesenjangan yang cukup dalam antara permintaan dan produksi daging sapi dalam negeri. Sebagai akibatnya tepaksa Indonesia harus mengimpor sapi dari luar dengan konsekuensi terkurasnya devisa negara dan terciptanya iklim yang kurang kondusif bagi peternak lokal. Untuk mengatasi permasalahan ini diperlukan adanya peningkatan produktivitas dan produksi sapi dalam negeri.

Peningkatan produktifitas dapat dicapai dengan cara meningkatkan populasi dan meningkatkan biomasa (bobot badan). Meningkatkan populasi membutuhkan waktu yang cukup lama, sedangkan meningkatkan biomasa dapat dilakukan melalui perbaikan manejemen dan pemberian pakan yang berkualitas (Wajo, 2008). Menurut Syamsu (2005), pengembangan sapi potong di suatu wilayah sangat tergantung pada tersedianya pakan hijauan sebagai pakan utama baik jumlah maupun mutu. Pakan sendiri dapat menyedot biaya produksi hingga 70-80 persen.

Sapi Bali berkontribusi sebesar $32.31 \%$ terhadap populasi sapi potong nasional (BPS 2016), yang merupakan peringkat pertama terbanyak, namun produktivitasnya masih rendah sama seperti sapi potong lokal lainnya. Secara umum rata-rata pertambahan bobot badan harian $(\mathrm{PBBH})$ sapi potong lokal di Indonesia hanya mencapai 0.37 kg/ekor/hari, sedangkan kondisi ideal yakni 0.8 - $0.9 \mathrm{~kg} / \mathrm{ekor} / \mathrm{hari}$, (Soedjana et al. (2012).

Besarnya biaya pakan ditentukan oleh jenis dan bangsa ternak. Kemampuan untuk menekan biaya pakan tanpa mengurangi kualitasnya dalam meningkatkan produktivitas ternak merupakan persyaratan mutlak bagi kelangsungan usaha peternakan. Untuk menjamin ketersediaan pakan hijauan bagi ternak dapat dilakukan konservasi hijauan dengan pembuatan hay atau silase. Pembuatan hay atau silase biasanya dilakukan untuk mengantisipasi kekurangan pakan pada musim kemarau. Namun dapat juga diaplikasikan guna memanfaatkan limbah pertanian.

Pemanfaatan jerami padi sebagai pakan ternak sapi potong masih termasuk kurang, hal ini karena adanya faktor-faktor pembatas dari jerami padi itu sendiri. Faktor-faktor pembatas itu antara lain rendahnya nilai protein dan tingginya kandungan serat kasar, hal ini menyebabkan nilai cerna pada ternak menjadi rendah. Menurut Haryanto et al. (2005), bahwa untuk meningkatkan kualitas jerami padi sebagai bahan pakan, maka faktor faktor tersebut perlu diatasi. Salah satu pendekatan adalah dengan perlakuan fermentasi menggunakan probion. Probion merupakan produk campuran berbagai macam mikroba yang dibuat melalui proses inkubasi an aerob isi rumen dengan tambahan mineral dan bahan organik yang dibutuhkan oleh mikroba.

Menurut Haryanto et al., (2009) Kandungan bahan kering jerami padi segar sekitar $40-45$ persen dan 
kebutuhan ternak sapi Bali adalah sekitar 6 - $7 \mathrm{~kg}$ bahan kering jerami/hari untuk sapi dengan bobot hidup $250 \mathrm{~kg}$. Sehingga dapat diprediksi potensi produksi bahan kering jerami padi di Manokwari pada areal sawah 4.136 ha adalah 19.853 - 22.334 ton/tahun. Potensi tersebut seharusnya dapat dimanfaatkan untuk pakan sapi sebanyak 8.741 - 9.065 ekor sapi/tahun. Pakan dari jerami padi tersebut harusnya dapat dimanfaatkan untuk menekan biaya pakan dan meningkatkan produktivitas ternak sapi.

Jumlah populasi sapi di Kabupaten Manokwari Papua Barat tahun 2015 mencapai 20.843 ekor ( BPS, 2016). Secara umum petani peternak belum memanfaatkan limbah jerami padi sebagai pakan ternak sapi. Disisi lain petani-peternak sapi merasa kesulitan mencari pakan ternak sapi bilamana musim tanam sedang berlangsung, hal ini disebabkan oleh lahan pengembalaan yang terbatas.

\section{Masalah Penelitian}

Pada saat musim panen, jerami padi berlimpah dan tidak termanfaatkan secara optimal, bila diberikan secara langsung hamper tidak disukai sapi (palatabilisnya sangat rendah). Sapi Bali sendiri memiliki kemampuan yang tinggi dalam memanfaatkan pakan berkualitas rendah dan mengkonversikannya menjadi daging. Perbaikan kualitas jerami padi melalui fermentasi dapat meningkatkan kualitas dan palatabilatas pakan jerami padi sehingga diharapkan dapat meningkatkan konerja sapi Bali jantan.

Tujuan Penelitian ini adalah unutk mengetahui produktivitas Sapi Bali jantan yang diberikan pakan rumput gajah yang disubtitusi dengan fermentasi jerami padi. Mengetahui potensi pakan jerami padi sebagai bahan pakan substitusi dengan rumput gajah.
Manfaat Penelitian ini adalah Pertani dapat memanfaatkan sumberdaya lokal yang mudah dan murah untuk memenuhi kebutuhan pakan sapi. Peternak sapi dapat memperoleh peningkatan produksi dan pendapatan melalui usaha pemggemukan sapi. Dalam waktu jangka panjang dapat menekan impor Sapi sekaligus memperbaiki iklim usaha bagi peternak sapi.

Pernelitian dilaksanakan selama 5 bulan, sejak bulan Mei sampai September tahun 2015, bertempat di SP-10 Distrik Sidey Kabupaten Manokwari. Lokasi ditentuklan secara porposiv dengan pertimbangan bahwa Distrik Sidey merupakan daerah pengembangan Sapi Bali di Kabupaten Manokwari. Selain itu di daerah tersebut terdapat banyak limbah jerami padi yang belum dimanfaatkan untuk pakan sapi.

Penelitian di rancangan dengan menggunakan Rancangan Acak Lengkap (RAL) Pola tersarang (Gomes and Gomes, 1995), dengan assumsi bahwa waktu penimbangan berat badan tersarang pada berat badan. Variabel yang diamati dalam penelitian ini adalah: Pertambahan berat badan (PBB) absolut, Pertambahan berat badan (PBB) relatif dan Potensi jerami padi ( $\mathrm{t} / \mathrm{ha} / \mathrm{musim}$ tanam). Untuk mengetahui pengaruh perlakuan yang diberikan, maka data ditabulasi dan dilakukan analisis varian menggunakan GLM (General Linier Model) dengan bantuan program SPSS Versi 21.

Pengumpulan dan pengambilan jerami padi dibutuhkan waktu selama 4 hari, pembuatan jerami padi fermentasi selama 21 hari, setelah 21 hari fermentasi jerami lalu diangin anginkan di atas para para agar jerami fermentasi tahan disimpan jadi waktu yang dibutuhkan adalah 25 hari. Proses fermentasi dengan penambahan probiotik dan urea. Fermentasi yang di-lakukan adalah dengan cara terbuka yakni jerami 
padi ditumpuk setebal $30 \mathrm{~cm}$, lalu ditambahkan probiotik dan urea. Dosis yang digunakan pada fermentasi tersebut adalah 2,5 $\mathrm{kg}$ probiotik dan 2,5 $\mathrm{kg}$ urea per satu ton jerami padi segar. Setelah proses pemberian probiotik dan urea, jerami tersebut disimpan atau diperam dalam terpal plastik selama 21 hari. Setelah diperam selama 21 hari jerami hasil fermentasi di simpan di para-para guna diangin-anginkan. Pem-buatan kandang sapi dalam bentuk sekat dengan ukuran 1,5 meter x 2 meter/ekor x 12 kandang sekat + kandang sekat untuk tempat penimbngan sap dan cor lantai kandang dibutuhkan waktu 2 minggu. Masa pengenalan pakan jerami fermentasi selama 1 minggu, dilanjutkan dengan masa penelitian selama 90 hari.

\section{HASIL DAN PEMBAHASAN}

\section{Bobot Badan Sapi Bali Jantan}

Hasil penelitian menunjukan bahwa tidak ada perbedaan yang signifikan antara bobot badan sapi Bali jantan yag diberi pakan rumput gajah (Pennisetum purpureum), dengan yang disubtitusi fermentasi jerami padi pada berbagai waktu penimbangan yang berbeda.

Dari Tabel 1. tersebut di atas bahwa variabel bobot badan sapi Bali jantan yang diberi pakan rumput gajah (Pennisetum purpureum) dengan subtitusi jerami padi tidak memperlihatkan perbedaan yang nyata $(\mathrm{P}>0,05)$. Namun demikian terlihat bahwa bobot badan terbaik adalah yang diberikan rumput gaja $100 \%$. Bobot badan sapi Bali jantan yang digunakan dalam penelitian ini secara normal dan memiliki variasi umur yang berkorelasi dengan produksi dan pertumbuhannya menyebar secara merata. Perlakuan JP0 (rumput gajah 100
\%) lebih baik dari perlakuan JP25 ( rumput gajah $75 \%$ + jerami fermentasi $25 \%$ ) dan JP50 (rumput gajah $50 \%+$ jerami fermentasi 50\%). Ini mengindikasikan bahwa limbah jerami padi yang difermentasikan dapat disubtitusi atau mengantikan rumput gaja (Pennisetum purpureum). Hal ini meru-pakan suatu hasil yang menggemberikan, karena para peternak dikawasan pertanian padi dapat mengembangkan sapinya, terutama sapi Bali dengan memanfaatkan limbah jerami padi yang berlimpah tersebut.

Dengan kata lain dapat dikatakan bahwa perlakuan pemberian jerami fermentasi yang mensubtitusi rumput gajah (Pennisetum purpureum) dapat dimanfaatkan sebagai bahan pakan untuk memanfaatkan limbah jerami padi yang berlimpah serta memiliki harga yang lebih murah atau juga gratis.

Pemberian pakan yang berkualitas akan mampu memberikan performa produksi seperti bobot badan pasca lahir, produksi susu selama bulan laktasi dan pertumbuhan pedet, serta mengurangi kematian pendet pada Sapi Bali (Bamualim, 2003). Secara umum dalam berbagai literatur dikatakan bahwa performa seekor ternak di-pengaruhi oleh $30 \%$ hereditas dan $70 \%$ lingkungan. Sehingga pemberian pakan fermentasi jerami padi dapat ditingkatkan kualitasnya lagi dengan penambahan pakan konsentrat.

\section{Pertabahan Bobot Badan}

Hasil penelitian menunjukan bahwa pertambahan bobot badan (PBB) berbeda nyata $(\mathrm{P}<0,05)$ pada berbagai waktu penimbangan, hal ini menunjukan bahwa subtitusi rumput gajah dengan fermentasi jerami padi pada berbagai perlakuan memberikan

Tabel 1. Rata-rata Bobot Badan Sapi Bali Jantan Dalam Berbagai Tingkat Perlakuan Pemberian Pakan dan Waktu Penimbangan

Bobot Badan $(\mathrm{kg}) \quad$ Total




\begin{tabular}{lccccc}
\hline $\begin{array}{l}\text { Perlakuan } \\
\text { Pemberian Pakan }\end{array}$ & Awal & Bulan I & Bulan II & Bulan III & \\
\hline JP0 & 188.13 & 203.25 & 219.750 & 237.75 & $212.22 \pm 39.77$ \\
JP25 & 152.25 & 166.38 & 178.750 & 191.25 & $172.16 \pm 16.63$ \\
JP50 & 127.13 & 138.25 & 148.500 & 160.88 & $143.69 \pm 14.84$ \\
\hline Rata-rata & 155.83 & 169.29 & 182.33 & 196.63 & $176.02 \pm 38.35$ \\
\hline
\end{tabular}

Pengaruh terhadap respon pertambahan berat badan Sapi Bali jantan. Pemerian pakan rumput gajah $100 \%$ adalah yang memiliki PBB yang tebaik dan diikuti oleh $25 \%$ dan yang terendah adalah $50 \%$ (Tabel 2). Hal ini di duga kemungkinan karena sapi belum beradaptasi secara baik dan juga palatabiltas jerami padi yang rendah sehingga sami tidak mau mengkonsumsinya. Hal ini jelas karena berat badan merupakan fungsi dari pakan yang diberikan dengan lama waktu yang dibutuhkan oleh ternak dalam mengkonversikan pakan tersebut menjadi daging serta organ-ogran lainnya.

\section{Pertabahan Bobot Badan Absolut}

Laju pertumbuhan absolut merupakan pertambahan bobot badan per unit waktu (Brody, 1945). Kurva laju pertumbuhan absolut diperoleh dengan cara menggambarkan pertambahan bobot badan harian versus umur. Pada saat lahir sampai pubertas terjadi peningkatan pertambahan bobot badan yang semakin meningkat. Setelah mencapai pubertas, laju pertambahan harian akan menurun hingga mencapai titik nol pada saat mencapai dewasa tubuh. Setelah itu laju pertumbuhan akan menjadi negatif.

Oematan (2000), melaporkan bahwa pertumbuhan kompensasi yang merupakan pertumbuhan absolut pada Sapi Bali adalah 998,63 $\pm 103,429$ kg/hari dari berat awal dengan laju pertumbuhan adalah 0.75-0.9 kg/hari. Pada penelitian ini ditemukan bahwa laju pertumbuhan absolut adalah $0.56-0.8 \mathrm{~kg} / \mathrm{ekor} / \mathrm{hari}$ (Tabel 3) berada dibawah hasil yang diperoleh Oematan (2000) namun berada di atas Wajo, (2015) yaitu $0,71 \mathrm{~kg} /$ ekor/hari, hal ini karena pakan yang diberikan oleh Oematan (2000) adalah pakan konsentrat yang memiliki nilai gizi yang tinggi dan terukur sedangkan Wajo memberikan pakan rumput alam dibawah naungan kelapa sawit. Namun bila dilihat sekilas bahwa hasil yang diperoleh cukup baik, sehingga dapat dikatakan bahwa pemberikan fermentasi jerami padi yang mensubtitusi rumput gajah hingga $50 \%$ masih mampu memberikan pengaruh yang baik pada pertumbuhan absolut bagi sapi Bali jantan.

Tabel 2. Rata- Rata Pertamban Bobot Badan (PBB) Sapi Bali Jantan Dalam Berbagai Tingkat Perlakuan Pemberian Pakan dan Waktu Penimbangan

\begin{tabular}{llccc}
\hline Perlakuan Pemberian Pakan & \multicolumn{3}{c}{ Bobot Badan (kg/bulan) } & \multirow{2}{*}{ Total } \\
\cline { 2 - 4 } & Bulan I & Bulan II & Bulan III & \\
\hline JP0 & 15.125 & 14.125 & 11.125 & $13.45 \pm 2,80$ \\
JP25 & 16.500 & 12.375 & 10.250 & $13.04 \pm 4.67$ \\
JP50 & 18.000 & 12.500 & 12.375 & $14.29 \pm 3.74$ \\
\hline Rata-rata & 16.54 & 13,00 & 11,25 & $13.60 \pm 3.74$ \\
\hline
\end{tabular}

Tabel 3. Rata Rata Laju Pertumbuhan Absolut Sapi Bali Jantan yang Diberikan Pakan Rumput Gajah yang Disubtitusikan dengan Fermentasi Jerami Padi 


\begin{tabular}{cc}
\hline Perlakuan & $\begin{array}{c}\text { Rata-Rata LajuPertumbuhan Absolut } \\
(\mathrm{kg} / \mathrm{hari})\end{array}$ \\
\hline JP0 & 0,83 \\
JP25 & 0,65 \\
JP50 & 0,56 \\
\hline Rata-rata & 0,68 \\
\hline
\end{tabular}

Penelitian ini juga menunjukkan bahwa laju pertubuhan absolut pada perlakuam JP0 (rumput gajah 100\%) $0,83 \mathrm{~kg} / \mathrm{hari}$ adalah yang tertinggi dibading dengan perlakuan JP25 (jerami padi $25 \%$ + rumput gajah $75 \%$ ) yaitu $0,65 \mathrm{~kg} / \mathrm{hari}$ dan yang terendah adalah perlakuan JP50 (jerami padi $50 \%+$ rumput gajah $50 \%) 0,56 \mathrm{~kg} / \mathrm{hari}$. Hal ini diduga karena faktor berat badan awal sapi Bali yang berbeda di samping itu faktor adaptasi yang tidak terlalu lama, karena dari beberapa penelitian menunjukkan bahwa tingkat palatabilitas rumput gajah lebih tinggi dari jerami padi fermentasi.

\section{Pertabahan Berat Badan Relatif}

Pertumbuhan relatif adalah kecepatan tumbuh absolut dibagi dengan setengah jumlah bobot badan awal dan bobot badan akhir pengamatan (Brody, 1945). Pertumbuhan bobot badan harian sapi-sapi Eropa (Bos taurus) lebih tinggi bila dibandingkan dengan sapi-sapi pada daerah tropis atau sapi-sapi Bos indicus termasuk sapi Bali (Bos sondaicus), namun persentase laju pertumbuhannya lebih kecil bila dibandingkan dengan Sapi Bali (Bos Sondaicus). Pertumbuhan relatif pada Sapi Bali dengan pemberian pakan yang berkualitas dapat mencapai 0,47-0,52 kg/hari (Oematan, 2000 dan Wajo, 2015). Hasil penelitian ini diperoleh bahwa rata-rata partumbuhan relatif adalah $0.033 \mathrm{~kg} / \mathrm{hari}$ (Tabel 4) dan hasil ini masih berada di bawah hasil yang diperoleh Oematan (2000) maupun Wajo (2015). Perbedaan ini jelas sekali karena pakan yang digunakan adalah berbeda dimana penelitian Oematan telah menggunakan pakan berkualitas berupa konsentrat sedangkan Wajo membiarkan pakan merumput secara bebas di bawah naunngan yang sejuk dan nyaman.

Namun dapat dilihat pula bahwa rata-rata laju pertumbuhan relatif dari ketiga perlakuan pakan JP0, JP25 dan JP50 adalah sama yakni $0,033 \mathrm{~kg} / \mathrm{hari}$. Ini berarti pemberian pakan rumput gajah dengan disubtusi jerami pada fermentasi tidak memberikan perbedaan yang signifikan terhadap laju pertumbuhan relatif.

Tabel 4. Rata Rata Laju Pertumbuhan Relatif Sapi Bali Jantan yang Diberikan Pakan Rumput Gajah yang Disubtitusikan dengan Fermentasi Jerami Padi

\begin{tabular}{cc}
\hline Perlakuan & $\begin{array}{c}\text { Rata-Rata Laju Pertumbuhan } \\
\text { Relatif }(\mathrm{kg} / \mathrm{hari})\end{array}$ \\
\hline JP0 & 0,033 \\
JP25 & 0,033 \\
JP50 & 0,033 \\
\hline Rata-rata & 0,033 \\
\hline
\end{tabular}

KESIMPULAN DAN SARAN
Dari hasil penelitian ini dapat ditarik kesimpulan sebagai berikut : 
1. Subtitusi rumput gajah (Penicetum purpureum) dengan fermentasi jerami padi hingga $50 \%$ tidak memberikan pengaruh yang signifikan terhadap pertambahan berat badan (PBB) sapi Bali jantan. Namun waktu pemberian jerami padi fermentasi yang mensubtitusi rumput gajah (Penicetum purpureum) berpengaruh secara signifikan terhadap berat badan sapi Bali jantan

2. Potensi jerami padi di kabupaten Manokwari dapat dapat dimanfaatkan sebagai pakan untuk sapi Bali sebanyak 9.421 - 46.846 ekor.

\section{Saran}

Penetian tentang pemanfaatan jerami padi fermentasi dengan Probion dan Urea sangat dianjurkan untuk dikaji terus menerus, hal ini dimungkinkan karena ketersedian jerami padi di Kabupaten Manokwari sangat berlimpah, dengan perlakuan fermentasi ditambah dengan konsetrat dapat meningkatkan nilai gizinya.

\section{DAFTAR PUSTAKA}

Badan Pusat Statistik., 2011 Pendataan Sapi Potong, Sapi Perah dan Kerbau (PSPK 2011). Jakarta (ID): Badan Pusat Statistik.

Badan Pusat Statistik., 2016.Papua Barat Dalam Angka Tahun 2016.

Badan Litbang Pertanian, 2013. Panduan Umum Model Pengembangan Pertanian Pedesaan Melalui Inovasi. Badan Litbang Pertanian.Kementerian Pertanian.

Brody., 1945. Dalam Prama.A., 2017. Kurva Sigmoid 1. Geogle Cendekia. 3.Mei 2017.

Ditjen Bina Produksi Peternakan. 2002. Buku Statistik Peternakan. Direktorat Jenderal Bina Produksi Peternakan. Jakarta
Gomes. K.A dan Gomes. A.A., 1995. Prosedur Statistik Untuk Penelitian Pertanian. Edisi Ke dua. Universitas Indonesia (UIPRESS)

Halili. H., 2014 Fermentasi Jerami Padi Analisis Kandungan Selulosa, Hemiselulosa, Lignin dan Silica Ransum Lengkap Berbahan Jerami Padi (Oriza Sativa), Daun Gamal dan UMML. Program Studi Nutrisi dan Makanan Ternak Universitas Hasanuddin Makassar.

Hanafi, N.D,. 2008. Teknologi Pengawetan Pakan Ternak. Departemen Peternakan Fakultas Pertanian Universitas Sumatra Utara. Medan.

Hartadi. H., S. Reksohadiprodjo dan A.D. Tillman. 1990 Tabel Komposisi Pakan untuk Indonesia. Gadjah Mada University Press, Yokyakarta.

Haryanto. B, Supriyati, A.Thalib dan S.N. Jermani., 2005. Peningkatan Nilai Hayati Jerami Padi Melalui Bio-Proses Fermentative dan penembahan Zinc Organik. Pros. Seminar Nasional Teknologi Peternakan dan Veteriner. Bogor, 12 - 13 September 2005. Puslitbang Peternakan Bogor. $473-478$.

Haryanto. B., 2007. Strategi Pemanfaatan Pakan Ternak Ruminansia. Materi Forum Komunikasi Peneliti-Penyuluh-Petani dalam Bidang Peternakan. Hotel Fujita Papua. 12 Desember 2007. Balai Pengkajian Teknologi Pertanian Papua Barat. Balai Besar Pengkajian dan pengembangan Teknologi Pertanian. Departemen Pertania.

Mahardi, 2009.Potensi Fermentasi Jerami Padi Sebagai Sumber Pakan Untuk Usaha Pengge- 
muka Sapi Potong.

http://mahardinutrisi06.blogspot. com/2009/05/jerami.html.

Diakses pada tanggal 29 Maret 2014.

Oematan, J. S. 2000. Pertumbuhan Kompensasi Sapi Bali Jantan pada Beberapa Imbangan Energi Protein Ransum dan Efek Terhadap Sifat-sifat Karkas. Program Pasca Sarjana IPB. Bogor.

Samsu J. A,. 2005. Integrasi Sapi Potong Dan Jagung. Gorontalo Pos. 15 April 2005.

Sastradipradja, D. 1990. Potensi Internal Sapi Bali Sebagai salah Satu Sumber Plasma Nutfah Untuk Menunjang Pembangunan Peternakan Sapi Potong dan ternak Kerja Secara Nasional. Prosiding seminar Nasional Sapi Bali, hlm. A47. Denpasar: Universitas Udayana.

Soedjana TD, Bahri S, Diwyanto K, Priyanti A, Ilham N, Muharsini S, Tiesnamurti B. 2012. Menakar potensi penyediaan daging sapi dan kerbau di dalam negeri menuju swasembada 2014. Pusat Penelitian Dan Pengembangan Peternakan. Badan Penelitian dan Pengembangan Pertanian, Kementerian Pertanian. Jakarta (ID)

Wajo, M.J. 2008. Potensi Ternak Sapi Bali di Distrik Bomberai Kabupaten Fakfak Papua Barat. Jurnal Berkala Ilmu Peternakan. 2 (1):20-23.

Wajo, M.J. 2015. Performa Produksi Sapi Bali Jantan yang Dipelihara Terintegrasi dengan Perkebunan Kelapa Sawit di Kabupaten manokwari papua Barat. Disertasi Doktoral. Fakultas Peternakan Universitas Padjajaran Bandung. (h: 41-60). 